\title{
OCULAR HYPERTENSION RISK FACTORS AND THERAPY?
}

\author{
Janicijevic Katarina, ${ }^{1}$ Kocic Sanja, ${ }^{1}$ Todorovic Dusan, ${ }^{1}$ Sarenac Vulovic Tatjana ${ }^{2}$ \\ ${ }^{1}$ Faculty of Medical Sciences, University of Kragujevac, Serbia \\ ${ }^{2}$ Clinic of Ophthalmology, Clinical Centre of Kragujevac, Serbia
}

Primljen/Received 11. 10. 2015. god.

Abstract: Introduction/Aim: The goal of our study was to analyze the epidemiological characteristics of ocular hypertension, as well as the influence of chronic risk factors on glaucoma development (conversion to glaucoma). We tried to make some entries for solving this complex ophthalmological problem. Material /Methods: From 2009 to 2015, a retrospective control study was performed on 121 patient with diagnoses of bilateral ocular hypertension and without disease progression/conversion of glaucoma (by standard protocols of diagnosis and basic procedures) on tertiary level at Clinic of Ophthalmology, Clinical Centre of Kragujevac, Serbia. The authors analyzed epidemiological characteristics: sex, age groups, positive/negative family history and personal history with chronic risk factors (one and/or two) of ocular hypertension. The data obtained from this study were statistically analyzed in SPSS program, version 20.0. Results: As for the patients, 69 of them (57.02\%) were male and 52 female (42.98\%). Dominant age group was between 409 (42.15\%) and then group between 509 $(40.50 \%)$ years of age. Anamnesis data indicated the absence of family anamnesis in $71(58.68 \%)$ patients. Risk factors for ocular hypertension were presented in 103 (85.13\%) patients, 18 of them (14.87\%) did not respond. One risk factor - cardiovascular disease was noted in 83 $(68.59 \%)$, two risk factors - cardiovascular diseases and diabetes mellitus in 20 patients $(16.53 \%)$ and PEX syndrome at other respondents. Conclusion: Ocular hypertension is not a common disease, but with risk factors, such as older age, positive family history, and chronic risk factors syndicated, represents a serious clinical and social problem, so the question remains for ophthalmologists - pro or against therapy? Those in favor of therapy would state the safety and protection from conversion/progression of glaucoma; but those against therapy would only mention adequate monitoring of patients.

Key words: ocular hypertension, epidemiology characteristics, risk factors, therapy.
Prihvaćen/Accepted 11. 11. 2015. god.

\section{INTRODUCTION/AIM}

Ocular hypertension is defined as intraocular pressure higher than $22 \mathrm{mmHg}$ with normal clinical appearance of the optic nerve head and no defects in frequency doubling by the perimetry tests. (1).

The disease doesn't prefer gender, but is more common in men, of middle-older-age, mostly without a positive family history and with associated the chronic risk factors, so it is up to the clinics to decide whether they are for or against the treatment (2). If the therapy is not applied, the mandatory general principal of ophthalmologist is to monitor their intraocular pressure, optic head condition and visual field defects (3).

The aim of this study is to determine what can create the risk of harmless ocular hypertension progression towards multi factorial glaucoma diseases of today, and to present an important discovery.

\section{MATERIAL AND METHODS}

The retrospective study conducted in the period from 2009 to 2015, included 121 patient from Clinic of Ophthalmology in Kragujevac, those with bilateral ocular hypertension but without disease progression at referent tertiary level as determined by the ambulatory-polyclinic observation of the patients. Patients were selected and followed up using standard protocols of patients who came to the Clinical Centre of Kragujevac, Serbia.

The criteria according to which the patients were selected to be included in the study were: IOP higher than $22 \mathrm{~mm} \mathrm{Hg}$ - ocular hypertension, daily fluctuations and target IOP, but without functional and morphological damage and the progression of disease.

The patients who were functional mono-oculus for any reason, those with secondary glaucoma, as well as those who had any eye-surgical treatment were excluded. 
IOP values were measured by Goldman applanation tonometer, while CCT values were determined using the ultrasonic pachymeter (ultrasonic pachymeter by renowned German manufacturer - Heidelberg Engineering, referent values $500-555 \mu \mathrm{m}$ ).

By measuring the central corneal thickness, we excluded the possibility that among our patients with thicker corneas there were candidates with ocular hypertension and therapy, and that among our patients with thinner corneas were potentials glaucoma patients with determined necessity for the therapy.

The regional Ethic Committee of Clinical Centre in Kragujevac (central Serbia) approved this study.

Patients were categorized into groups based on intraocular pressure, daily fluctuations, target IOP, cup-to-disc ratio (obtained by indirect fundus examination morphological damages), and visual field parameters (obtained by three Octopus perimetry tests - functional damages).

Authors analyzed the epidemiological characteristics: sex, age group, family history related to ophthalmologic problems (ocular hypertension or glaucoma) and the personal history with the chronic risk factors (cardiovascular diseases, diabetes mellitus and PEX syndrome).

The data obtained in this study were statistically analyzed in the SPSS program, version 20.00. The frequency analysis was performed by Chi-square test ( $\mathrm{p}$-values include the exact value unless it is less than 0.05).

\section{RESULTS}

There was no statistically significant difference between the sex representation in our study - 69 males $(57.02 \%)$ and 52 females $(42.98 \%)\left(\chi^{2}=2.338, \mathrm{p}=\right.$ 0.122), (Table 1).

Dominant age groups were between 40-49 (42.15\%) and 50-59 (40.50\%) years of age (the average age was
47.31 years \pm 0.79$)$. The analysis of age indicated a statistically significant difference between age groups $\left(\chi^{2}\right.$ $=13.950, \mathrm{p}=0.001),($ Table 1$)$. Authors also conducted the partial analysis and found that the number of patients in the first age group was significantly different from the number in the second $\left(\chi^{2}=12.500, \mathrm{p}=\right.$ $0.000)$, and the third age group $\left(\chi^{2}=1.200, p=0.001\right)$. However the number of patients in the second and third age groups were slightly different $\left(\chi^{2}=0.040, p=\right.$ 0.841 ), so that there was no statistical significance.

The anamnesis data indicated that 71 (58.68\%) patient had no family history with ophthalmologic problems, while $50(41.32 \%)$ respondents had such history, (Table 1). The analysis by positive/negative family history indicated no statistically significant difference $\left(\chi^{2}=3.645, p=0.056\right)$. The conclusion that family history had no influence could be disputable, because the p-value was very close to the limit value of 0.05 . The risk factors were noticed in $103(85.13 \%)$ patients, while $18(14.87 \%)$ of them did not show any.

We had $83(68.59 \%)$ patients with one chronic risk factor (cardiovascular diseases) and 20 (16.53\%) patients with two chronic risk factors (cardiovascular diseases and diabetes mellitus), while PEX syndroma was noted in other patients - $20(14,88 \%)$. There were no patients with all three risk factors, (Table 1).

Our results indicated that the largest number of patients had one risk factor: cardiovascular disease or diabetes mellitus; but the small number of them had two risk factors (cardiovascular disease and diabetes mellitus), with a statistically significant difference in number of these patients $-\left(\chi^{2}=38.534, p=0.000\right)$. Among the patients with one risk factor for ocular hypertension, patients with PEX and diabetes mellitus were similar and with statistically significantly difference $\left(\chi^{2}=9.389, p=0.002\right)$ in correlation with patients with only cardiovascular disease. These date indicated that patients with PEX or diabetes mellitus had

Table 1. The epidemiological characteristics (age, gender, family history) and risk factors for ocular hypertension (cardiovascular diseases, diabetes mellitus, PEX syndroma)

\begin{tabular}{|c|c|c|c|c|c|c|c|c|c|c|c|}
\hline \multirow{2}{*}{ Age } & $\begin{array}{c}30-39 \\
\text { years }\end{array}$ & $\begin{array}{c}40-49 \\
\text { years }\end{array}$ & $\begin{array}{c}50-59 \\
\text { years }\end{array}$ & \multicolumn{2}{|c|}{ Sex } & \multicolumn{2}{|c|}{$\begin{array}{c}\text { Family } \\
\text { history }\end{array}$} & \multicolumn{5}{|c|}{ Risk factors } & $\begin{array}{c}\text { Number } \\
\text { Ocular patients } \\
\text { hypertension }\end{array}$ & $\begin{array}{c}\text { Ocular } \\
\text { hypertension }\end{array}$ & $\begin{array}{c}\text { Ocular } \\
\text { hypertension }\end{array}$ & M & F & + & - & $\begin{array}{c}\text { Cardiovas. } \\
\text { diseases }\end{array}$ & DM & $\begin{array}{c}\text { PEX } \\
\text { Sy }\end{array}$ & \\
\hline $2009-2011$ & 2 & 13 & 12 & 14 & 13 & 12 & 15 & 4 & 5 & 10 & $\begin{array}{c}27 \\
22.31 \%\end{array}$ \\
\hline $2011-2013$ & 3 & 15 & 15 & 18 & 15 & 13 & 20 & 6 & 5 & 15 & 33 \\
\hline $2013-2015$ & 16 & 23 & 22 & 37 & 24 & 25 & 36 & 21 & 13 & 24 & $\begin{array}{c}61 \\
50.41 \%\end{array}$ \\
\hline$\Sigma 6$ & 21 & 51 & 49 & 69 & 52 & 50 & 71 & $\Sigma 31$ & $\Sigma 23$ & $\Sigma 49$ & $\Sigma 121$ \\
\hline
\end{tabular}


different other conditions which can ameliorate eye condition- positive condition for ocular hypertension development. The analysis showed that incidence of cardiovascular disease and diabetes mellitus were not significantly different $\left(\chi^{2}=1.185, \mathrm{p}=0.276\right)$. It also indicated that greater number of our patients had cardiovascular disease than diabetes mellitus, but without statistical significant difference $\left(\chi^{2}=4.050, \mathrm{p}=0.044\right)$.

Correlation of the risk factors and the values of intraocular pressure was not the aim of our study.

All CCT values, determined by ultrasonic pachymeter, were in referent values 500-555 im, as daily fluctuations and target IOP, so we did not use those data for the statistical analysis, too.

The treatment of ocular hypertension is an intrigant question. We cannot exactly give the suggestion with the very beginning of the therapy, as well as which medications can be used in these cases. Our suggestion is to watch over all of the results and measurements, with the deep insight in the health of every patients. The treatment of ocular hypertension was not the aim of this study, because we merely wanted to clarify the risk factors.

\section{DISCUSSION}

A number of patients did not differ significantly by gender, but differed by age groups in favor of the second and third groups (the older patients). It was concluded that the older patients (as it is commonly known), and the patients with one or two risk factors needed the anti glaucoma therapy as the preventive therapy for the diagnosis of ocular hypertension.

Negative family history also had a great impact on the potential number of the other risk factors, such as cardiovascular diseases, diabetes mellitus and PEX syndrome.

The risk factors are the main in the evolution of ocular hypertension and represent an obstacle in the progress. They are also taking into the account making decisions about the treatment for prevention of the disease progression or conversion in glaucoma.

Many authors determined the prevalence of pseudoexfoliation syndrome (PEX) in Lithuanian urban population and its association with ischemic heart disease (IHD), arterial hypertension (AH) and diabetes mellitus (DM). No clear PEX syndrome association with IHD, AH and DM was proven after controlling the effect of age (1).

Ocular hypertension is frequent (about 3.6\%) in the adult Chinese population with the age of $40+$ years. Associated factors are diabetes mellitus and arterial hypertension. The diabetes mellitus and arterial hypertension should be checked in ocular hypertensive subjects (2).
However, some of studies available on systemic findings in glaucoma patients are contradictory, making further research necessary to identify the exact role of such disturbances in pathogenesis of the damage. Moreover, it is not always clear whether we are dealing with coincidence or true association between glaucoma and the particular systemic disease, which is why the authors presented this retrospective study (3).

Popa et al., cited that the arterial hypertension, diabetes mellitus, atherosclerosis and vasospasms in developed glaucoma were the main risk factors (4). We considered the same risk factors to determine the development from clinical diagnosis of harmless ocular hypertension to the potential glaucoma.

Ocular hypertension is present when intraocular pressure is above the range considered as normal (22 $\mathrm{mmHg}$ ), without detectable changes of visual field and no damage to the eye structures. The term is used to distinguish between people with elevated pressure but without a developed glaucomatous disease and those without it. There is an increased risk for glaucoma among the patients with elevated ocular tension and that is why, according to the authors opinion, regular comprehensive eye examinations are essential for the overall eye health (5).

Evaluating the results of ocular fundus examinations for signs of hypertensive retinopathy in combination with the assessment of the presence or absence of other known vascular risk factors may allow clinicians to further individualize the risk profile of each individual patient, thus permitting more accurate risk stratification and potentially guiding treatment strategies, as to be used in our future researches (6).

These data suggested that, although diabetes and metabolic abnormalities may be associated with the small increase in intraocular pressure, they were not significant risk factors for glaucomatous optic neuropathy $(7,8)$. The other authors showed that metabolic syndrome was a risk factor for high ocular tension (9), which was also the case with our patients, as to be used in our future researches, too.

Zhao et al., recommended a single evening dose of the combination of latanoprost and timolol in reducing IOP in Chinese subjects with primary open angle glaucoma or ocular hypertension, whose intraocular pressure was insufficiently reduced with $\beta$-blocker mono therapy or $\beta$-blocker-based dual therapy (10), which according to our opinion is justified when the transmission from harmless ocular hypertension to glaucoma has already taken place.

Tzamalis A. et al., indicated that the type of tonometry could also help us in making a decision in which cases to treat ocular hypertension. The difference between dynamic contour tonometry (DCT) and Gold- 
mann applanation tonometry (GAT) IOP measurements is found statistically significantly higher in patients receiving Carbonic Anhydrase Inhibitors (CAIs) either as monotherapy or as a part of a combined ocular hypotensive treatment, while DCT and GAT readings remain unaffected (11).

Patients with diabetes mellitus, as well as with cardiovascular disease should be considered as high risk patients for converting ocular hypertension to glaucoma. Therefore, it is necessary to conduct serious examinations in order to decide when to start glaucoma treatment $(12,13)$.

Based on our findings and other relevant data, it is our suggestion that protocols for ocular hypertension should be precisely filed allowing ophthalmologists to have exact entries for deciding when to treat ocular hypertension and when to establish glauocomatous diagnosis (14).

Long-term IOP fluctuations do not appear to be significantly associated with the risk of developing glaucoma in untreated ocular hypertensive patients. With this study we also established that IOP fluctuation did not exactly determine the conversion of ocular hypertension in glaucoma (15).

St mer et al., noted that we should treat the patients with IOP higher than $32 \mathrm{~mm} \mathrm{Hg}$, but also that we should seriously consider their ophthalmological condition by using some kind of risk calculator. It is necessary to consider the risk factor but we also need to take into account the IOP values. The principal of atchful waiting is the best for the patients with ocular hypertension, and the treatment should start immediately if morphological or functional progression has been noted (16).

The data suggested that also we must consider all risks, as well as benefits and alternatives for this serious ophthalmological problem $(17,18)$.

Studies in this ophthalmological area are very interesting for ophthalmologists because they help us resolve very difficult problems. The EGPS (European Glaucoma Prevention Study) did not demonstrate that reducing intraocular pressure with dorzolamide actually prevented the onset of glaucoma, compared to the individuals receiving a placebo. The investigators of the OHTS (Ocular Hypertension Treatment Study) found that the treatment of ocular hypertension could be delayed with topical medication when treated patients were compared with an observation group. EGPS also suggested that age, thin corneal thickness measure- ments, large cup-to-disc ratio and mean IOP are the main criteria for determining the treatment. However, the ultimate decision when to apply the treatment can also be determined by other factors such as life expectancy, the general health of the patient and the number of risk factors (19).

It is also very important to determine the target IOP for every individual patient. Target IOP can presume the outcome of ocular hypertension (20).

\section{CONCLUSION}

Ocular hypertension is often missed to be diagnosed as a disease, due to the presence of a number of risk factors such as age, associated chronic risk diseases, etc, which poses a dilemma before ophthalmologists, to apply a therapy or not?

The question of the therapy for ocular hypertension stays open for now and only adequate monitoring and more frequent controls of these patients can help us to detect the disease in early stage and proceed with the initial therapy that would serve as a preventive therapy against individual disease conversion/progression. If we decide not to apply the therapy to our ocular hypertensive patients, we then definitely should proceed with monitoring them through ophthalmological and cardiovascular examinations.

With this study the authors attempted to determine the risks of harmless ocular hypertension progressing into glaucoma disease. The results can serve for establishing more solid grounds for making decision in relation to the application of therapy and for further investigations into this matter.
Abbreviations
PEX syndrome - pseudoexfoliative syndrome
IOP - intraocular pressure
CCT - central corneal thickness
CVD - cardiovascular disease
DM - diabetes mellitus
IHD — schemic heart disease
AH - rterial hypertension
EGPS - European Glaucoma Prevention Study
OHTS - Ocular Hypertension Treatment Study

\section{Conflict of interest}

We confirm that no actual or potential conflict of interest exists in relation to this article. 


\title{
Sažetak
}

\section{OKULARNA HIPERTENZIJA — FAKTORI RIZIKA I TERAPIJA?}

\author{
Janicijevic Katarina, ${ }^{1}$ Kocic Sanja, ${ }^{1}$ Todorovic Dusan, ${ }^{1}$ Sarenac Vulovic Tatjana ${ }^{2}$ \\ ${ }^{1}$ Faculty of Medical Sciences, University of Kragujevac, Serbia \\ ${ }^{2}$ Clinic of Ophthalmology, Clinical Centre of Kragujevac, Serbia
}

Uvod/Cilj: Cilj studije je bio da se analiziraju epidemiološke karakteristike okularne hipertenzije, kao i uticaj hroničnih faktora rizika za okularnu hipertenziju (konverzije u glaukom). Pokušali smo da napravimo neke odrednice za rešavanje ovog kompleksnog oftalmološkog problema.

Materijal i Metode: Retrospektivna, kontrolisana studija u periodu od 2009. do 2015. uključila je 121 pacijenta sa obostranom kliničkom dijagnozom okularne hipertenzije, bez progresije bolesti/konverzije u glaukom, upotrebom standardnih protokola i osnovnih dijagnostičkih procedura na tercijalnom nivou, Klinike za Oftalmologiju, Kliničkog Centra Kragujvac, Srbija. Analizirane su epidemiološke karakteristike: pol, starosne grupe, pozitivna/negativna porodična anamneza $\mathrm{i}$ individualni hronični faktori rizika (jedan $\mathrm{i} / \mathrm{ili} \mathrm{dva)} \mathrm{za}$ okularnu hipertenziju. Podaci studije su statistički obrađeni i analizirani u SPSS programu, verzija 20,00.

Rezultati: Od ukupnog broja pacijenata, muškaraca je bilo 69 (57,02\%), a žena 52 (42,98\%). Dominantna sta-

\section{REFERENCES}

1. Spečkauskas M, Tamošiãnas A, Jašinskas V. Association of ocular pseudoexfoliation syndrome with ischaemic heart disease, arterial hypertension and diabetes mellitus. Acta Ophthalmol. 2012; 90(6): 470-5.

2. Xu L, Wang YX, Jonas JB, Wang YS, Wang S. Ocular hypertension and diabetes mellitus in the Beijing Eye Study. J Glaucoma. 2009; 18(1): 21-5.

3. Pache M. Primary open-angle glaucoma and systemic diseases. Ophthalmologe. 2007; 104(5): 431-41.

4. Popa SA, Bucãtariu PM, Costin D, Manole A, Mate MC, Merchez M. Contributions to know the involvement of cardio-vascular diseases in glaucoma etiology, studied on a sample of 996 patients assisted in Clinic of Ophthalmology, rof. N. Oblu Emergency Hospital, Iasi. Rev Med Chir Soc Med Nat Iasi. 2011; 115(1): 127-32.

5. Stefan C, Dumitrica DM, Dragomir L, Cristea I, Sapundgieva A. Ocular hypertension-follow up or treatment? Oftalmologia. 2009; 53(2): 23-5.

6. Henderson AD, Bruce BB, Newman Nj, Biousse V. Hypertension-related eye abnormalities and the risk of stroke. Rev Neurol Dis. 2011; 8(1-2): 1-9.

7. Tan GS, Wong TY, Fong CW, Aung T; Singapore Malay Eye Study. Diabetes, metabolic abnormalities and glaucoma. Arch Ophthalmol. 2009; 127(10): 1354-61.

8. Primus S, Harris A, Siesky BA, Guidoboni G. Diabetes: a risk factor for glaucoma? Br J Ophthalmol. 2011; 95(12): 1621-2. rosna grupa je bila od 40-49 godina sa najvećom učestalošću pacijenata $42,15 \%$, a zatim starosna grupa od 50-59 godina sa učestalošću 40,50\%. Anamnestički podaci ukazuju da je 71 pacijent $(58,68 \%)$ bilo bez pozitivne porodične anamneze. Faktori rizika okularne hiperztenzije, kao hronične bolesti su nađeni kod 103 (85,13\%), a bez kod 18 $(14,87 \%)$ pacijenata. Sa jednim faktorom rizika (kardiovaskularna bolest) je bilo 83 (68,59\%), sa dva faktora rizika (kardiovaskularna bolest i šećerna bolest) je bilo 20 (16,53\%), a sa PEX sindromom ostali ispitanici. Zaključak: Okularna hipertenzija kao samostalno oboljenje nije česta, ali sa faktorima rizika, kao sto su starije doba, pozitivna porodična anamneza i udruženi hronični faktori rizika (jedan i/ili dva), predstavlja ozbiljan kliničko-socijalni problem, a pred oftalmologe postavlja pitanje, za ili protiv terapije? Odgovor za terapiju, je zaštita od konverzije i progresije u glaukom, a odgovor protiv terapije, je samo adekvatno praćenje pacijenata.

Ključne reči: okularna hipertenzija, epidemiološke karakteristike, faktori rizika, terapija.

9. Imai K, Hamaguchi M, Mori K, et al. Metabolic syndrome as a risk factor for high-ocular tension. Int J Obes (Lond). 2010; 34(7): 1209-17.

10. Zhao JL, Ge J, Li XX, et al. Comparative efficacy and safety of the fixed versus unfixed combination of latanoprost and timolol in Chinese patients with open-angle glaucoma or ocular hypertension. BMC Ophthalmol. 2011; 11:23.

11. Tzamalis A, Kynigopoulos M, Chalvatzis N, Dimitrakos S, Schlote T. Association of ocular hypotensive medication types with dynamic contour tonometry and Goldmann applanation tonometry measurements in a glaucoma and ocular hypertensive population. J Ocul Pharmacol Ther. 2013; 29(1): 41-7.

12. Swymer C, Neville MW. Tafluprost: the first preservative-free prostaglandin to treat open-angle glaucoma and ocular hypertension. Ann Pharmacother. 2012; 46(11): 1506-10.

13. Apreutesei NA, Chiselita D, Motas OI. Glaucoma evolution in patients with diabetes. Rev Med Chir Soc Med Nat Iasi. 2014; 118(3): 667-74.

14. Chan PP, Leung CK, Chiu V, et al. Protocol-driven adjustment of ocular hypotensive medication in patients at low risk of conversion to glaucoma. Br J Ophthalmol. 2015;99(9): 1245-50.

15. Medeiros FA, Weinreb RN, Zangwill LM, et al. Long-term intraocular pressure fluctuations and risk of conversion from ocular hypertension to glaucoma. Ophthalmology. 2008; 115(6): 934-40.

16. St mer J. Arguments against pressure-lowering treatment of ocular hypertension. Prophylactic treatment is unnecessary. Ophthalmologe. 2011; 108(11): 1006-10. 
17. Fechtner RD, Khouri AS. Evolving global risk assessment of ocular hypertension to glaucoma. Curr Opin Ophthalmol. 2007; 18(2): 104-9.

18. Lee BL, Wilson MR. Ocular Hypertension Treatment Study (OHTS) commentary. Curr Opin Ophthalmol. 2003; 14(2): 74-7.

\section{Correspondence to /Autor za korespondenciju}

Janicijevic M. Katarina

Faculty of Medical Sciences,

University of Kragujevac, Serbia

Svetozara Markovica 69, 34000 Kragujevac, Serbia

Tel: +38134369828

Mob: +381642183797

Fax: +38134370073

email:kaja.andreja@yahoo.com
19. Higginbotham EJ. Treating ocular hypertension to reduce glaucoma risk: when to treat? Drugs. 2006; 66(8): 1033-9.

20. Laplace O, Bron A, Nordmann JP. Management of ocular hypertension and chronic open-angle glaucoma by French ophthalmologists: the role of target intraocular pressure. J Fr Ophtalmol. 2006; 29(4): 353-8. 